NOTHING BUT THE TRUTH. By Joseph Berger. New York: The John Day Co., 1971. 286 pp. $\$ 8.95$.

The author is a Communist of a particular sort. Born in Poland, he first emigrated as a very young man to Palestine as a Zionist, and in 1922 he helped to found there a Communist party of which he became the secretary. After a stay in Moscow in 1924-25, followed by several missions to the Near East on behalf of the Communist International, he became a militant and permanent official of the Comintern from 1932 to 1934 , having adopted Soviet citizenship. Like so many others and without any known reason, he was arrested in January 1935, after which he spent twenty-one years in a dozen prisons and concentration camps. "Rehabilitated" after Stalin's death, he was able to leave Russia, thanks to his Polish origin, and settled in Israel, where he wrote this remarkable eyewitness report.

How he could reconcile Zionism and Marxism-ideologies that are mutually exclusive (if the words and ideas have any meaning) - he does not explain. Nor does he explain his persisting loyalty to communism after the experiences he lived through, when so many denials had been given by practice to theory. He himself tells how it was when, after fifteen years of separation from his family, his son and wife (cruelly persecuted on his account) were able to visit him in Siberia: "Unlike me, he and his mother had broken with Marxist ideology and it was difficult for the three of us to find a common language on many subjects" (p. 213). It is true that his is not the communism of the founders of the Third International, since he owed his offices to Stalin's regime.

Berger endured the worst kind of treatment and privation in the course of his interminable sufferings. Condemned to death without rhyme or reason, he conducted two long hunger strikes in order to affirm the rights of the human being. One wonders how he could have survived. And he testifies for the sake of history with remarkable serenity, without weeping and gnashing of teeth. He knew almost all the categories of victims to the Stalinist terror regime-sons of illustrious families (a Loris-Melikov, an Obolensky), writers, Communist officials, Trotskyists, Mensheviks, religious persons-and he conveys their words to an indifferent free world. His poignant account will take its place in the series of authentic eyewitness accounts, written in the blood of martyrs, which will remain to characterize a world and an era.

Boris Souvarine Paris

MAGADAN. By Michael Solomon. Foreword by Irving Layton. Princeton, New York, Philadelphia, London: Auerbach Publishers, 1971. Published in Canada by Chateau Books. x, 243 pp. $\$ 7.95$.

THE SILVER MADONNA. By Eugenia Wasilewska. Foreword by Arthur Cook. New York: John Day, 1971. 216 pp. \$5.95.

Neither of these books appears to be intended for scholars, and their value to scholars is questionable. They seem intended rather for the general reader, invited in the case of the Solomon book to read a story comparable to One Day in the Life of Ivan Denisovich and in the case of the Wasilewska book to read about "a brave young woman's remarkable flight to freedom." In both the setting is basically Stalin's Russia. 
Michael Solomon is a Rumanian Jewish journalist who fought with the forces of the British Middle East Command in Egypt and East Africa during World War II. At the conclusion of the war he elected to return to Rumania and resume his journalistic career. Full of idealism and like many others unable at first to comprehend the significance of the tightening Communist controls over Rumania, this sophisticated journalist, who had also served in London before the war, was clearly not a fit subject for Ana Pauker's Rumania. He was first arrested by the Rumanian security police in February 1948. Released in June of that year, he was immediately picked up by the Russian police and soon sentenced to a twenty-fiveyear term in the forced labor camps north of Magadan. When the Russians released him in 1955, he was rearrested by the Rumanian police and held in Rumanian prisons for another ten years.

Magadan is the story of how he managed to survive the rigors of camp life in that northern Siberian region. It should be compared not to the Solzhenitsyn novel, as claimed by the publisher, but to Eugenia Ginzburg's Journey into the Whirlwind. However, it falls far short of Mrs. Ginzburg's achievement. Solomon's writing is both pretentious and pedestrian, and the reviewer found that his interest in the story frequently lagged.

Mrs. Wasilewska was exiled to a remote village, and her story is not concerned with forced labor camps. The seventeen-year-old daughter in 1939 of a Polish landowner in the western Ukrainian province of Rovno, she and members of her family were deported to a village near Novo Sukhotino in northern Kazakhstan several months after Russian troops occupied the province in the fall of 1939. After over a year of hardship in exile, during the course of which she married and separated from her husband, she resolved in the spring of 1941, upon learning that she was pregnant, to attempt to join her father in German-occupied Poland. A little more than half of the book is concerned with her hazardous journey by rail and foot westward toward the Ukraine. The story is simply told, and there is an element of suspense which makes the book more readable than Magadan. It should nevertheless be noted that Mrs. Wasilewska consistently calls the region to which she was deported "Siberia" and in the very few references she makes to the Oriental natives she always calls them "Khirgiz." Clearly an escape story about Stalin's Russia is bound to be that much more gruesome and suspenseful if the escape is from Siberia rather than Kazakhstan.

JACOB WALKIN

Auburn University

\section{DOGMATISMUS UND EMANZIPATION IN DER SOWJETUNION: PHILOSOPHIE, REFORMDENKEN, OPPOSITION. By Kurt Marko. Stuttgart: Verlag W. Kohlhammer, 1971. 224 pp. DM 19.80, paper.}

This book is a rather successful attempt to tell the story of current ideologicalphilosophical developments in the Soviet Union. The difficulty in telling this story lies in relating it to the classical Marxist-Leninist philosophical "establishment," on the one hand, and to political developments which need explanation, on the other. The price of success is a certain looseness of organization which makes it hard to read the book in one sitting and rather encourages one to read it as a series of essays that are similar in intent but very different in conceptualization. The titles of the chapters are "When Does Paradise Begin?," "Soviet Philosophy Between 